\title{
Physical, psychosocial, and organisational factors relative to sickness absence: a study based on Sweden Post
}

\author{
M Voss, B Floderus, F Diderichsen
}

\begin{abstract}
Objective-To analyse incidence of sickness for women and men relative to potential aetiological factors at workphysical, psychosocial, and organisational.

Methods-The study group comprised 1557 female and 1913 male employees of Sweden Post. Sickness absence was measured by incidence of sickness (sick leave events and person-days at risk). Information on explanatory factors was obtained by a postal questionnaire, and incidence of sickness was based on administrative files of the company.
\end{abstract}

Results-Complaints about heavy lifting and monotonous movements were associated with increased risk of high incidence of sickness among both women and men. For heavy lifting, an odds ratio (OR) of $1.70(95 \%$ confidence interval (95\% CI) 1.22 to 2.39 ) among women, and OR 1.70 (1.20 to 2.41) among men was found. For monotonous movements the risk estimates were OR 1.42 (1.03 to 1.97$)$ and $O R$ 1.45 (1.08 to 1.95$)$ for women and men, respectively. Working instead of taking sick leave when ill, was more prevalent in the group with a high incidence of sickness (OR 1.74 (1.30 to 2.33) for women, OR 1.60 (1.22 to 2.10) for men). Overtime work of more than 50 hours a year was linked with low incidence of sickness for women and men. Among women, $16 \%$ reported bullying at the workplace, which was linked with a doubled risk of high incidence of sickness (OR 1.91 (1.31 to 2.77)). For men, the strongest association was found for those reporting anxiety about reorganisation of the workplace (OR 1.93 (1.34 to 2.77)).

Conclusions-Certain physical, psychosocial, and organisational factors were important determinants of incidence of sickness, independently of each other. Some of the associations were sex specific. (Occup Environ Med 2001;58:178-184)

Keywords: incidence of sickness; work environment; sex Health Sciences, Division of Social Medicine, Karolinska Institutet, Stockholm, Sweden

F Diderichsen

Correspondence to:

M Voss

margaretha.voss@imm.ki.se

Accepted 29 November 2000

Regulations in the welfare system, the economic situation (unemployment and depression in the economy), social circumstances, environmental factors at work, and individual behaviours are some important determinants in the multifactorial aetiology of sickness absence. ${ }^{12}$ Studies of occupational groups show that blue collar and junior white collar workers have a higher level of sickness absence than senior white collar workers. ${ }^{3-8}$ The incidence of sickness absence and the number of absences per person are highest among young workers, and falls as age increases. ${ }^{9-11}$ Short periods of sick leave are more common among younger and long periods among older workers. ${ }^{6891112}$ Furthermore, women have a higher rate of absence and more days of sickness absence than men, ${ }^{13-5} 91012-14$ and working hours, family situation, and children are of significance in this context. ${ }^{1412}$

Conditions at work-such as heavy, physically arduous, or monotonous tasks-increase the risk of ill health. ${ }^{12}{ }^{15-17}$ Grade of employment, work organisation, and the psychosocial work environment may also be important for health and wellbeing. ${ }^{7212^{18-20}}$ In the 1980s, Karasek and Theorell ${ }^{21}$ suggested that job demands in combination with job control had a significant impact, and that high job demands in combination with low control are associated with, for example, coronary heart disease and musculoskeletal diseases. Few studies on sickness absence fully support the job demands-job control model ${ }^{12}{ }^{19}$ whereas most find a partly positive impact on sickness absence from low job control or low job demands. ${ }^{14} 20$ 22-23 There are few studies where both physical and psychosocial work environment factors are analysed simultaneously relative to sickness absence. ${ }^{1}{ }^{122324}$ Blank and Diderichsen ${ }^{12}$ showed that high physical demands at work, high psychological demands (for women), and the demand-control relations were associated with repeated short and long spells of sickness absence. Furthermore, Smulders and Nijhuis ${ }^{23}$ found that previous absence, age, and health had greater implications on sickness absence than job control, job demand, or the physical work environment (temperature, air, noise, and odour). Frost et $a l^{24}$ analysing chemical and physical exposures (as one variable), found a slightly higher association with sickness absence for this type of exposure compared with psychosocial factors. Sickness absence is not simply an indicator of ill health, but should also be regarded as reflecting a conscious choice on the part of the person based on factors that encourage or discourage absence or presence at work - that is, a form of coping behaviour. ${ }^{192526}$

Several studies on sickness absence have been carried out in the Scandinavian countries ${ }^{13591012131516192224}$ but there are also investigations from the United Kingdom, France, and the Netherlands. ${ }^{4681423}$ In a study 
Table 1 Age distribution and sickness incidence for women and men eligible for the study and for respondents of the questionnaire

\begin{tabular}{|c|c|c|c|c|c|c|}
\hline & \multicolumn{2}{|c|}{ Eligible for the study } & \multicolumn{4}{|c|}{ Respondents * } \\
\hline & $\begin{array}{l}\text { Women } \\
n\end{array}$ & $\begin{array}{l}M e n \\
n\end{array}$ & $\begin{array}{l}\text { Women } \\
n\end{array}$ & $\%$ & $\begin{array}{l}\text { Men } \\
n\end{array}$ & $\%$ \\
\hline & 1557 & 1913 & 1226 & 78.7 & 1410 & 73.7 \\
\hline Mean age & 42.8 & 39.5 & 42.9 & & 39.5 & \\
\hline Median age & 44 & 39 & 45 & & 39 & \\
\hline Sickness incidence† & 52.2 & 46.1 & 49.8 & & 41.4 & \\
\hline
\end{tabular}

*Eight workers lacking information about days at risk were excluded.

tCrude sickness incidence/10 000 days at risk.

by Prins and de Graaf, comparing sickness absence in different Belgian, German, and Dutch firms, the authors concluded that country specific characteristics may be strong determinants, and that extrapolation from one country to another should be made with caution. ${ }^{11}$

The aim of the present study was to give a multifactorial background of sickness absence, and to spot factors which may have a significant impact on the occurrence of sick leave events. Different features of the physical and psychosocial work environment as well as work organisation were studied, based on data from the Sweden Post. The availability of comparable data for women and men enabled an evaluation of sex differences.

\section{Materials and methods}

The study population consisted of all employees in three of Sweden Post's regional organisations: Letter Division Sundsvall, Letter Division Umeå, and Sales Division Sundsvall. Encompassed by the study were all people with regular employment contracts (full time or part time) since 1 July 1992, who were employed for at least 6 months during 1993, and who were still employed in the same region in September 1994. This made a total of 3470 people, 1557 women and 1913 men, representing occupational tasks with considerable variation in the physical demands they impose-administrators, cashiers, mail handling staff, rural postmen, office personnel, office cleaning staff, computer personnel, and technicians.

\section{INCIDENCE OF SICKNESS}

Data on sickness absence were available from Sweden Post's register of absenteeism. It was measured by the incidence of sickness in 1993 and was computed for each person by dividing the number of sickness events by "days at risk". Days at risk were obtained by taking the number of calendar days in the year, subtracting the number of days absent from work, regardless of cause. Incidence of sickness is expressed as number of sickness events per 10000 days at risk. Recurrent sickness absence within 5 days was handled as one and the same event.

On the basis of the distribution of incidence of sickness, two categories were formed: low incidence, corresponding to roughly less than two events a year, and high incidence, corresponding to about two or more events a year. Thirty per cent of women and $34 \%$ of men had no registered sickness events at all in 1993.
The low incidence group comprised people with $0-55.25$ sickness events/10 000 days at risk $(60 \%)$ and the high incidence group comprised people with more than 55.25 sickness events/10 000 days at risk $(40 \%)$.

\section{WORK RELATED FACTORS}

A questionnaire was posted in the autumn of 1994. The response rate was $76.0 \%$, with a higher proportion of respondents among women $(78.7 \%)$ than among men $(73.7 \%)$. The findings of the study are based on data obtained from 1219 women and 1409 men-a total of 2628 people (excluding eight for whom information on days at risk was lacking). The study group by sex is presented in table 1 . Respondents were identifiable and their questionnaire data were linked to the personal files on presence or absence from work (the linkage was approved by informed consent from the study subjects). The questionnaire comprised questions about the physical, psychosocial, and organisational situation at the workplace during 1993. Often we used the phrasing developed in previous studies. ${ }^{27} 28$

A total of 150 variables representing the studied areas were analysed one at a time and subsequently by multivariate models:

- The workplace and the work-size of the workplace, work as a supervisor, teamwork, and proportion of women and men at the workplace.

- Environmental physical factors and work load-heavy lifting, work postures, technical aid, noise, lighting conditions, indoor climate, pollution, ventilation, smoke, cleaning, adjustment of tables and chairs, work with visual display units, outdoor work, and use of a vehicle at work.

- Working hours - full time or part time work, shift work, flexible working hours, desired working hours, overtime work, and additional source of income.

- Workmates and managers-support and encouragement, justice at the workplace, information, social relations, and occurrence of bullying at work. Bullying is defined as harassing, ganging up on someone, or psychologically terrorising others at work according to Leymann. ${ }^{29}$

- Work organisation - time pressure, workload, short breaks, time off duty, demands and ability, acquired experience, possibility of education and training, monotonous work, and degree of independence.

- Anxiety - anxiety about forthcoming changes at the workplace, anxiety of illness due to work.

- Relation between work, family life, and leisure time-negative interaction.

- Illness - working instead of sick leave, time off duty (vacation or overtime compensation) instead of sick leave and handling of work tasks when absent due to illness.

STATISTICAL ANALYSES

The answers for each of the 150 variables were dichotomised (exposed or not exposed) and related to sickness absence, adjusting for age. Multivariate analyses comprising all variables 
Table 2 High sickness incidence: univariate and multivariate analyses of work related factors for women

\begin{tabular}{|c|c|c|c|}
\hline Variables* & $\begin{array}{l}\text { Exposed cases } \\
(n)\end{array}$ & $\begin{array}{l}\text { Multivariate analyses } \\
\text { OR }(95 \% C I)\end{array}$ & $\begin{array}{l}\text { Univariate analyses } \\
\text { OR }(95 \% \mathrm{CI}) t\end{array}$ \\
\hline \multicolumn{4}{|l|}{ The workplace and the work: } \\
\hline No supervisor position & 448 & $1.01(0.68$ to 1.50$)$ & $1.38(1.00$ to 1.92$)$ \\
\hline Workplace $>50$ employees & 133 & $1.46(1.03$ to 2.07$)$ & $1.74(1.29$ to 2.33$)$ \\
\hline Workteam member & 253 & $1.29(0.96$ to 1.72$)$ & $1.45(1.15$ to 1.84$)$ \\
\hline \multicolumn{4}{|l|}{ Environmental physical factors and work load: } \\
\hline Complaints due to heavy lifting at work & 209 & $1.70(1.22$ to 2.39$)$ & $2.52(1.96$ to 3.24$)$ \\
\hline Complaints due to monotonous movements & 263 & $1.42(1.03$ to 1.97$)$ & $2.38(1.88$ to 3.01$)$ \\
\hline Complaints due to work in a forward bent position & 84 & $2.41(1.46$ to 3.98$)$ & $3.63(2.46$ to 5.36$)$ \\
\hline \multicolumn{4}{|l|}{ Working hours: } \\
\hline >50 hours overtime work during 1993 & 130 & $0.58(0.43$ to 0.79$)$ & $0.61(0.47$ to 0.78$)$ \\
\hline \multicolumn{4}{|l|}{ Workmates and managers: } \\
\hline Seldom or never possibility to discuss with the supervisor & 230 & 1.37 (1.03 to 1.83$)$ & $1.43(1.13$ to 1.81$)$ \\
\hline Seldom or never information meetings & 202 & $0.68(0.50$ to 0.91$)$ & $0.75(0.59$ to 0.95$)$ \\
\hline Social contacts by active participation in trade union work & 72 & $1.59(1.03$ to 2.44$)$ & $1.48(1.04$ to 2.11$)$ \\
\hline Work related contacts outside the workplace & 146 & $0.70(0.52$ to 0.95$)$ & $0.73(0.57$ to 0.93$)$ \\
\hline Occurrence of bullying at the workplace & 115 & $1.91(1.31$ to 2.77$)$ & $2.24(1.64$ to 3.07$)$ \\
\hline \multicolumn{4}{|l|}{ Work organisation: } \\
\hline Few or no possibilities of education and training & 262 & $1.18(0.88$ to 1.58$)$ & $1.56(1.24$ to 1.97$)$ \\
\hline \multicolumn{4}{|l|}{ Anxiety: } \\
\hline Anxiety of illness due to work & 279 & $1.02(0.76$ to 1.37$)$ & $1.79(1.42$ to 2.25$)$ \\
\hline \multicolumn{4}{|l|}{ Illness: } \\
\hline Have been working instead of taking sick leave & 244 & $1.74(1.30$ to 2.33$)$ & $2.07(1.62$ to 2.64$)$ \\
\hline Sick leave: duties are carried out by colleagues & 190 & $1.00(0.73$ to 1.37$)$ & $1.56(1.21$ to 2.01$)$ \\
\hline \multicolumn{4}{|l|}{ Age $(y) \ddagger:$} \\
\hline $31-40$ & 111 & $0.79(0.51$ to 1.22$)$ & $0.80(0.55$ to 1.16$)$ \\
\hline $41-50$ & 176 & $0.85(0.56$ to 1.30$)$ & $0.71(0.51$ to 1.00$)$ \\
\hline$>50$ & 139 & $1.23(0.77$ to 1.96$)$ & $0.86(0.60$ to 1.23$)$ \\
\hline
\end{tabular}

*The wording of the variables refers to the exposure, and other responses were unexposed. The italics indicate variables that were included in the final multivariate model.

†Age adjusted Mantel-Haenszel.

$\ddagger$ Compared with women younger than 31 .

within each was then carried out, to select the most important area specific variables. Subsequently, the independent effects of these variables were assessed in a final multivariate model. The selection criteria for variables to be included in the area specific models and in the final model were: an increased relative risk and a lower confidence limit $\geqslant 0.95$, or a decreased relative risk and an upper confidence limit $\leqslant 1.05$.

We used the statistical analysis system (SAS $6.12),{ }^{30}$ and the multivariate analyses were performed by logistic regression (LOGISTIC), yielding odds ratios (ORs) with 95\% confidence intervals (95\% CIs). Three factors showing strong associations with sickness absence for

Table 3 High sickness incidence: univariate and multivariate analyses of work related factors for men

\begin{tabular}{|c|c|c|c|}
\hline Variables $^{\star}$ & $\begin{array}{l}\text { Exposed cases } \\
(n)\end{array}$ & $\begin{array}{l}\text { Multivariate analyses } \\
\text { OR }(95 \% C I)\end{array}$ & $\begin{array}{l}\text { Univariate analyses } \\
\text { OR }(95 \% \mathrm{CI}) t\end{array}$ \\
\hline \multicolumn{4}{|l|}{ The workplace and the work: } \\
\hline No supervisor position & 426 & $1.39(0.99$ to 1.95$)$ & 1.93 (1.48 to 2.52$)$ \\
\hline \multicolumn{4}{|l|}{ Environmental physical factors and work load: } \\
\hline Complaints due to heavy lifting at work & 146 & $1.70(1.20$ to 2.41$)$ & $2.46(1.88$ to 3.22$)$ \\
\hline Complaints due to monotonous movements & 218 & $1.45(1.08$ to 1.95$)$ & $2.12(1.68$ to 2.67$)$ \\
\hline Work in a forward bent position & 303 & $1.05(0.80$ to 1.38$)$ & $1.58(1.27$ to 1.97$)$ \\
\hline Noise & 314 & $1.29(0.99$ to 1.69$)$ & $1.64(1.32$ to 2.04$)$ \\
\hline Bad lighting conditions & 295 & $1.03(0.79$ to 1.35$)$ & $1.60(1.28$ to 1.99$)$ \\
\hline No possibility to adjust the chair & 52 & $1.40(0.89$ to 2.20$)$ & $1.74(1.16$ to 2.59$)$ \\
\hline Work with visual display units & 101 & $1.27(0.90$ to 1.80$)$ & $0.63(0.48$ to 0.82$)$ \\
\hline \multicolumn{4}{|l|}{ Working hours: } \\
\hline Desire to have flexible working hours & 201 & $1.26(0.96$ to 1.65$)$ & $1.54(1.22$ to 1.94$)$ \\
\hline >50 hours overtime work during 1993 & 187 & $0.70(0.53$ to 0.91$)$ & $0.76(0.61$ to 0.96$)$ \\
\hline \multicolumn{4}{|l|}{ Workmates and managers: } \\
\hline Seldom or never get sufficient information & 348 & $1.03(0.78$ to 1.36$)$ & $1.58(1.26$ to 1.98$)$ \\
\hline \multicolumn{4}{|l|}{ Work organization: } \\
\hline Cannot decide when to take short breakes & 280 & $1.14(0.87$ to 1.48$)$ & $1.70(1.37$ to 2.12$)$ \\
\hline Cannot make or take private telephone calls & 198 & $1.21(0.92$ to 1.59$)$ & $1.58(1.25$ to 2.00$)$ \\
\hline The job is nothing to be proud of & 240 & $1.17(0.89$ to 1.53$)$ & $1.76(1.40$ to 2.20$)$ \\
\hline Seldom or never possibility to postpone duties & 439 & $1.05(0.75$ to 1.48$)$ & $1.93(1.48$ to 2.52$)$ \\
\hline 1 to 5 days of education during 1993 & 39 & $1.04(0.63$ to 1.72$)$ & $0.45(0.31$ to 0.67$)$ \\
\hline \multicolumn{4}{|l|}{ Anxiety: } \\
\hline Often anxiety of illness due to work & 257 & $1.16(0.88$ to 1.53$)$ & $1.74(1.40$ to 2.18$)$ \\
\hline Often anxiety about reorganisation of the workplace & 143 & $1.93(1.34$ to 2.77$)$ & $2.04(1.56$ to 2.66$)$ \\
\hline Often anxiety about new techniques at the workplace & 164 & $1.19(0.89$ to 1.59$)$ & $1.51(1.18$ to 1.93$)$ \\
\hline Often anxiety about downsizing at the workplace & 191 & $0.62(0.45$ to 0.85$)$ & $1.22(0.97$ to 1.54$)$ \\
\hline \multicolumn{4}{|l|}{ Illness: } \\
\hline Have been working instead of taking sick leave & 367 & $1.60(1.22$ to 2.10$)$ & $2.14(1.70$ to 2.69$)$ \\
\hline Sick leave: duties are carried out by colleagues & 211 & $1.54(1.13$ to 2.09$)$ & $1.47(1.17$ to 1.86$)$ \\
\hline Sick leave: duties are carried out by temporary employees & 344 & $1.63(1.20$ to 2.20$)$ & $1.55(1.24$ to 1.94$)$ \\
\hline \multicolumn{4}{|l|}{ Age (y) $\ddagger$ : } \\
\hline $31-40$ & 199 & $0.81(0.57$ to 1.14$)$ & $0.75(0.56$ to 1.01$)$ \\
\hline $41-50$ & 149 & $0.49(0.34$ to 0.70$)$ & $0.43(0.32$ to 0.59$)$ \\
\hline$>50$ & 49 & $0.60(0.37$ to 0.98$)$ & $0.44(0.29$ to 0.66$)$ \\
\hline
\end{tabular}

*The wording of the variables refers to the exposure, and other responses were unexposed. The italics indicate variables that were included in the final multivariate model.

†Age adjusted Mantel-Haenszel.

$\ddagger$ Compared with men younger than 31 . 
Table 4 Interactions between important determinants of sick leave for women and men

\begin{tabular}{|c|c|c|c|c|}
\hline $\begin{array}{l}\text { Exposure to determinants by age } \\
(y)\end{array}$ & $0: 1^{\star}$ & $1: 0^{\star}$ & $1: 1^{\star}$ & Synergy indext \\
\hline \multicolumn{5}{|l|}{ Women: } \\
\hline \multicolumn{5}{|c|}{ Complaints due to heavy lifting: working instead of taking sick leave: } \\
\hline All & $1.81(1.27$ to 2.57$)$ & $1.82(1.20$ to 2.78$)$ & $2.90(1.85$ to 4.53$)$ & $1.17(0.56$ to 2.41$)$ \\
\hline$<41$ & $1.37(0.83$ to 2.25$)$ & $1.14(0.50$ to 2.57$)$ & $3.48(1.70$ to 7.11$)$ & $4.94(0.46$ to 53.24$)$ \\
\hline$>40$ & $2.30(1.36$ to 3.87$)$ & $1.99(1.19$ to 3.31$)$ & $2.38(1.32$ to 4.29$)$ & $0.60(0.22$ to 1.65$)$ \\
\hline \multicolumn{5}{|c|}{ Complaints due to heavy lifting : occurence of bullying at the workplace: } \\
\hline All & $2.01(1.28$ to 3.15$)$ & $1.77(1.24$ to 2.53$)$ & $3.03(1.62$ to 5.66$)$ & $1.14(0.41$ to 3.13$)$ \\
\hline$<41$ & $2.04(1.08$ to 3.85$)$ & $2.02(1.10$ to 3.69$)$ & $2.85(1.15$ to 7.02$)$ & $0.90(0.20$ to 3.95$)$ \\
\hline$>40$ & $1.83(0.95$ to 3.54$)$ & $1.62(1.03$ to 2.55$)$ & $2.75(1.13$ to 6.74$)$ & $1.21(0.26$ to 5.72$)$ \\
\hline \multicolumn{5}{|l|}{ Men: } \\
\hline \multicolumn{5}{|c|}{ Anxiety about reorganisation of the workplace: complaints due to heavy lifting: } \\
\hline All & $1.95(1.37$ to 2.79$)$ & $2.25(1.53$ to 3.32$)$ & $3.12(1.77$ to 5.49$)$ & $0.96(0.42$ to 2.23$)$ \\
\hline$<41$ & $1.69(1.05$ to 2.73$)$ & $2.57(1.55$ to 4.26$)$ & $2.39(1.13$ to 5.07$)$ & $0.61(0.17$ to 2.23$)$ \\
\hline$>40$ & $2.52(1.46$ to 4.34$)$ & $2.07(1.10$ to 3.89$)$ & $4.63(1.95$ to 10.99$)$ & $1.40(0.46$ to 4.26$)$ \\
\hline \multicolumn{5}{|c|}{ Anxiety about reorganisation of the workplace: working instead of taking sick leave: } \\
\hline All & $1.52(1.15$ to 2.00$)$ & $1.33(0.72$ to 2.48$)$ & $3.65(2.40$ to 5.56$)$ & $3.11(1.04$ to 9.27$)$ \\
\hline$<41$ & $1.49(1.04$ to 2.15$)$ & $1.59(0.72$ to 3.53$)$ & $3.74(2.15$ to 6.53$)$ & $2.53(0.70$ to 9.14$)$ \\
\hline$>40$ & $1.62(1.06$ to 2.48$)$ & $1.11(0.39$ to 3.14$)$ & $3.92(2.03$ to 7.57$)$ & $4.02(0.62$ to 26.07$)$ \\
\hline
\end{tabular}

$\star_{0}=$ Unexposed, $1=$ exposed; first factor:second factor. OR ( $\left.95 \% \mathrm{CI}\right)$ adjusted for variables according to tables 2 , 3. The reference group $(\mathrm{RR}=1)$ refers to cases and referents among the workers unexposed to both factors $(0: 0)$.

†Synergy index $(95 \% \mathrm{CI}) 1=$ no interaction; 2 =an effect among those with combined exposure twice what would be expected from additivity of effects.

women and men, respectively, were analysed for possible synergistic effects (the extent to which the presence of one factor influenced the effect of the other) following methods suggested by Rothman. ${ }^{31}$ A synergy index of 1 means no interaction, and a synergy index of 2 means an effect among those with combined exposure that are twice as big as would be expected from additivity of the two exposures. The analyses were carried out by computer programs described by Lundberg et al. ${ }^{32}$

\section{Results}

INCIDENCE OF SICKNESS

We found a slightly higher level of incidence of sickness for women than for men (table 1). Men in the older age groups (31-40, 41-50 and $>50$ years of age) showed a decreased risk of high incidence of sickness compared with the youngest age group ( $<31$ years of age), and the same tendency was found for women (bottom part of tables 2 and 3).

WORK RELATED FACTORS AND INCIDENCE OF SICKNESS

Women

Based on the outcome of the first series of analyses, 16 variables were retained for the final multivariate model (table 2). The strongest association was for problems related to working in a forward bent position. Women reporting such problems had a more than doubled risk of being in the group with high incidence of sickness compared with women who did not report these problems. Women with problems related to heavy lifting or monotonous movements also showed an increased risk of sickness absence. Furthermore, occurrence of bullying at the workplace almost doubled the risk of being in the group with high incidence of sickness. Other features associated with a high sickness absence were workplace with more than 50 people, being a work team member, seldom or never able to discuss with the supervisor, and social contacts by active participation in trade union work. Women who had been working instead of taking sick leave when ill also showed an increased incidence of sickness. A synergis- tic effect was suggested among younger women between working instead of taking sick leave and complaints due to heavy lifting, but the numbers were small (table 4).

Overtime work of more than 50 hours during 1993, seldom or never attended information meetings, and work related contacts outside their own workplace, showed a negative association with sickness absence (table 2).

\section{Men}

The first series of analyses (table 3 ) resulted in 23 variables for the final multivariate model. Anxiety of reorganisation showed the strongest association for men with incidence of sickness. After adjustment for other factors, the risk of being in the group with a high incidence of sickness was twice that of men who did not worry about reorganisations. Problems related to heavy lifting or to monotonous movements were also associated with sickness absence-as for women. Men reporting exposure to noise had a greater risk of an increased incidence of sickness. The same was found for men without a supervisory position and those who would have preferred flexible working hours. As for women, men who reported that they had been working instead of taking sick leave when they were ill, had a greater risk of high incidence of sickness. How the work was handled in a case of sickness absence was also linked with sickness absence - a high incidence was associated with situations where colleagues or temporary staff were taking care of the duties. A synergistic effect between working instead of taking sick leave and anxiety about reorganisation was found for men (table 4). A threefold increase in the relative risk was found for men with both determinants.

A decreased risk of sickness absence was found for men who reported over time work of more than 50 hours during 1993, and for men who experienced anxiety about downsizing (table 3).

\section{Discussion}

The aim of the study was to elucidate incidence of sickness relative to specific characteristics of 
potential aetiological factors at workphysical, psychosocial, and organisationalwith use of comparable data for women and men. Multivariate methods were used to adjust for mutual dependence between the factors. Information about the working conditions was available on an individual level, which is an advantage compared with studies based on job task descriptions or occupations as proxies for different exposures. Another advantage was the objective measurements of sickness absence obtained from administrative files.

Sickness absence is mostly defined as the sick role a person takes in a situation with illness (subjective ill health), disease (medical diagnosis), or in situations not involving illness or disease. In this study we could not separate these aspects from each other, and the study did not focus on specific diagnoses or symptoms. The most common way of measuring sickness absenteeism is by the sick leave ratethat is, total number of sickness days divided by number of people or person-days in the study group. But this measure has certain disadvantages, in particular that isolated cases of long sick leave can have a major impact on results (especially if the study group is small). We have preferred a measure reflecting for how long employees had been at work on average before sick leave was taken rather than for how long (on average) they were absent from work-the incidence of sickness. Incidence of sickness has also been used in earlier studies of postal employees in Sweden ${ }^{13}{ }^{33}$ as well as in some studies from other countries. ${ }^{71434}$ The measure has also been discussed by Hensing et al. ${ }^{35}$ The higher incidence of sickness for women compared with men and the difference between age groups found in this study correspond to previous findings, ${ }^{3-8}$ which indicates that the employees of Sweden Post are comparable with other study groups in these respects.

It cannot be ruled out that some of our findings could be caused by chance, because of the extensive number of variables analysed. However, all variables included in the questionnaire were motivated by hypotheses at the outset .

Complaints related to heavy lifting and to monotonous movements showed an association among both women and men with increased risk of high incidence of sickness (tables 2 and 3). Our results are consistant with previous findings, where physically strenuous work has been related to sickness absence. ${ }^{12} 15$ Although the work environment has changed during the past decade due to new technology and new types of work, statistics from Sweden ${ }^{36}$ show that employees still, to a great extent, perform strenuous work tasks. In 1997, 14\% of women and $21 \%$ of men reported that they had to lift 15-25 kg several times a day. Ten per cent of women and $19 \%$ of men reported physically strenuous work for at least a quarter of the day, and twisted work position (at least a quarter of the day) was reported by $28 \%$ and $27 \%$ of women and men, respectively.

Working instead of taking sick leave when ill was associated with high sickness absence among both women and men. This could be due to the fact that "sick working" is more prevalent among people with recurrent sickness events or that sick working leads to increased illness. From 1 April 1993, the compensation system for sickness absence was changed in Sweden-by a qualification day without sickness benefit. To avoid reduction of wages employees with frequent sickness absence might have been forced to work instead of taking sick leave for economic reasons. In the long run, these employees may run the risk of having more serious problems or illness with longer periods of sick leave, and may have to make greater efforts to rehabilitate. An association between low sickness absence and overtime work of more than 50 hours during 1993 was found for both women and men. This can probably be explained by good health or commitment to work. Also in this case it is hard to predict the long term consequences on health and wellbeing.

For women the strongest association with sickness absence was found for those reporting problems related to work in a forward bent position, which more than doubled the risk (table 2). This corroborates the findings on female nursing personnel where the most important factor for care seeking for low back symptoms was work in a forward bent position. ${ }^{17}$

Occurrence of bullying at the workplace was reported by $16 \%$ of the women and was associated with a twofold increase in the relative risk. It may be that bullying is a marker of a social climate, causing sickness absence-even if you are not exposed to bullying yourself. We deliberately asked about both personal experience of bullying and the occurrence of bullying in general to capture this psychosocial phenomenon, because personal questions may have low sensitivity. Eight per cent of the women were exposed to bullying themselves, which is higher than previous findings in Sweden $(3.5 \%)^{29}$ but corresponds to a Norwegian study $(8.6 \%$ during the previous 6 months). ${ }^{37}$

Active participation in trade union work was more prevalent among women in the group with high incidence of sickness and may be a marker of an increased workload including extensive social support to others. Work related contacts outside the workplace, on the other hand, were associated with a low incidence of sickness and may reflect a social network caused by or leading to good health.

For men the strongest association was found for those reporting anxiety about reorganisation of the workplace - with an almost doubled relative risk. Reorganisation may carry threats to the position and work experience with adverse effects on health and wellbeing. Synergistic effects are often difficult to pinpoint due to low statistical precision. We found, however, a synergistic effect in this study between anxiety about reorganisation and working instead of taking sick leave among men.

The correlation between anxiety about downsizing and anxiety about reorganisation of the company was 0.51 (Pearson). Anxiety about downsizing controlling for anxiety about reorganisation of the company was associated with low incidence of sickness. Downsizing 
may be an even stronger threat (compared with reorganisation), involving the possibility of unemployment, forcing the worker to minimise sickness absence. During the study period, Sweden Post experienced extensive organisational changes, resulting in downsizing of about $20 \%$ of the personnel between the beginning of 1992 and the end of 1994 (unpublished statistics). In a situation of downsizing, employers may choose to keep their healthier employees, because the employer bears the financial burden for the first 14 days of sick leave (since January 1992). An association between downsizing and decreased short term sick leave (1-3 days) was also reported by Vahtera et al. ${ }^{34}$

The concept of demand and control in the work situation introduced by Karasek and Theorell ${ }^{21}$ has been studied relative to sickness absence. $^{71419202223}$ Our questionnaire was not designed to measure these dimensions specifically, but some variables reflecting low control-for example, no possibility of taking or making private telephone calls-showed an association with high incidence of sickness. These factors did not remain important in the multivariate analyses.

It has been suggested that an even proportion of women and men at a workplace has a positive effect on sickness absence and reduced rates of sick leave. ${ }^{3}$ Our study did not support this hypothesis.

The cross sectional study design gives rise to some questions about interpretations. Collecting information about the exposures in retrospect sometimes entails uncertainty about the direction of the cause-effect relations. Exposures for 1993 were assessed during the end of 1994, which may introduce recall bias. Random errors in this respect, or underreporting of exposures, independent of the sickness absence, will have a diluting effect on the associations found. If, on the other hand, the person's pattern of sickness absence is associated with for example, a negative attidude, which might have affected her or his responses to the questionnaire, this could lead to an overestimated or false positive association. We do not think that our findings are influenced greatly by this type of bias, because the assessment of sickness absence was based on data collected from an independent data source, and also because the type of factors explored are mostly objective and should not be heavily influenced by subjective perceptions.

Non-respondents had a higher incidence of sickness than respondents (table 1). We do not know whether or not their answers would have strengthened the results. Furthermore, the selection of people into the study, excluding employees at work less than 6 months in 1993 set restrictions on generalisability - our study group should have an overrepresentation of healthy workers.

\section{Conclusions}

The study shows that physical, psychosocial, and organisational factors are related to incidence of sickness. Some of the factors were important for both women and men, but there were also sex specific results. The most impor- tant determinants were for women: complaints due to work in a forward bent position; complaints due to heavy lifting at work; occurrence of bullying at the workplace; and have been working instead of taking sick leave; and for men: often anxiety about reorganisation at the workplace; complaints due to heavy lifting at work; and have been working instead of taking sick leave. Future research of sickness absence should have a comprehensive view of the work environment including the physical, psychosocial, and organisational situation, and also a sex perspective on these questions.

This study was supported by three of Sweden Post's regional organisations: Letter Division Sundsvall, Letter Division Umeå, and Sales Division Sundsvall. We thank Hannu Kiviranta, Mariedal Konsult AB, for help with data entry and programming. 1 Vogel J, Kindlund H, Diderichsen F. Arbetsförhållanden,
ohälsa och sjukfrånvaro 1975-89. (Working conditions, health ohälsa och sjukfrånvaro 1975-89. (Working conditions, health and sickness absenteeism 1975-89). Sto

2 Taylor P. Absenteeism, causes and control of. In: Parmeggiani L, ed. Encyclopaedia of occupational health and safety, 3rd ed. Genève: International Labour Organisation, 1983: 5-8.

3 Alexanderson $\mathrm{K}$, Leijon $\mathrm{M}$, Åkerlind I, et al. Epidemiology of sickness absence in a Swedish county in 1985, 1986, and 1987. Scand F Soc Med 1994;22:27-34.

4 Chevalier A, Luce D, Blanc C, et al. Sickness absence at the French National Electric and Gas Company. Br F Ind Med 1987;44:101-10.

5 Diderichsen F. Sjukfrånvaro och förtidspension varierar kraftigt mellan olika yrken. (Sickness absence and early retirement pension vary considerably between different retirement pension vary considerably between
occupations). Läkartidningen 1990;87:179-84.

6 Marmot M, Feeney A, Shipley MJ, et al. Sickness absence as Marmot M, Feeney A, Shipley MJ, et al. Sickness absence as
a measure of health status and functioning: from the UK Whitehall II study. $\mathcal{F}$ Epidemiol Community Health 1995;49: 124-30.

7 North F, Syme SL, Feeney A, et al. Explaining socioeconomic differences in sickness absence: the Whitehall II study. BMF 1993;306:361-6.

8 Sharp C, Watt S. A study of absence rates in male and female employees working in occupations of equal status. Occup Med 1995;45:131-6.

9 Isacsson A, Hansson BS, Janzon L, et al. The epidemiology of sick leave in an urban population in Malmö, Sweden. Scand F Soc Med 1992;20:234-9.

10 Tellnes G, Bjerkedal T. Epidemiology of sickness certification: a methodological approach based on a study from Buskerud County in Norway. Scand F Soc Med 1989; 17:245-51.

11 Prins R, de Graaf A. Comparison of sickness absence in Belgian, German and Dutch firms. Br F Ind Med 1986;43: 529-36.

12 Blank N, Diderichsen F. Short term and long term sick leave in Sweden: relationships with social circumstances, working conditions and gender. Scand F Soc Med 1995;23:26572

13 Knave B, Paulsson H, Floderus B, et al. Incidence of work related disorders and absenteeism as tools in the implementation of work environment improvements: the Sweden Post strategy. Ergonomics 1991;34:841-8

14 Niedhammer I, Bugel I, Goldberg $M$, et al. Psychosocial factors at work and sickness absence in the Gazel cohort: a prospective study. Occup Environ Med 1998;55:735-41.

15 Ekberg K, Wildhagen I. Long-term sickness absence due to musculoskeletal disorders: the necessary intervention of work conditions. Scand F Rehabil Med 1996;28:39-47.

16 Tellnes G, Bruusgaard D, Sandvik L. Occupational factors in sickness certification. Scand $\mathcal{f}$ Prim Health Care 1990;8: in 374 .

17 Josephson $M$, Vingård E. Workplace factors and care seeking for low-back pain among female nursing personnel. MUSIC-Norrtälje Study Group. Scand $\mathcal{F}$ Work Environ Health 1998;24:465-72.

18 Marmot MG, Shipley MJ, Rose G. Inequalities in death: specific explanations of general pattern? Lancet 1984; 1003-6.

19 Kristensen TS. Sickness absence and work strain among Danish slaughterhouse workers: an analysis of absence from work regarded as coping behaviour. Soc Sci Med 1991;32:15-27.

20 North FM, Syme SL, Feeney A, et al. Psychosocial work environment and sickness absence among British civil servants: the Whitehall II study. Am $\mathcal{F}$ Public Health 1996;86:332-40

21 Karasek R, Theorell T. Healthy work. Stress, productivity and the reconstruction of working life. New York: Basic Books, 1990.

22 Kivimäki M, Vahtera J, Thomson L, et al. Psychosocial factors predicting employee sickness absence during economic decline. F Appl Psychol 1997;82:858-72. 
23 Smulders P, Nijhuis F. The job demands-job control model and absence behaviour: results of a 3 year longitudinal and absence behaviour: results of
study. Work Stress 1999;13:115-31.

24 Frost P, Breddam E, Bendsen J, et al. Sygefravær i relation til arbejdsmiljø og familieforhold. (Sick leave in relation to working conditions and family structure). Ugeskr Lager 1995;157:2856-60.

25 Kristenssen TS. Sygefravær som coping. (Sickness absence as a coping strategy). Socialmedicinsk Tidskrift 1995;1:12-7.

26 Rael EGS, Stansfeld SA, Shipley MJ, et al. Sickness absence in the Whitehall II study, London: the role of social support
and material problems. F Epidemiol Community Health 1995;49:474-81.

27 Bergqvist U, Knave B, Voss $M$, et al. A longitudinal study of VDT work and health. Intnational fournal of HumanComputer Interaction 1992;4:197-219.

28 Statistics Sweden (SCB). Undersökningen av levnadsförhållanden, ULF. (Surveys of living conditions.) Stockholm: Stalanden, ULF. (Surveys of living conditions.) Stockholm: Sta-
tistics Sweden, 1989 .

29 Leymann H. The conter work. European fournal of Work and Organizational Psychol ogy 1996;5:165-84.

30 SAS Institute. SAS/STAT user's guide, version 6, 4 ed. Cary, NC: SAS Institute, 1994.
31 Rothman K. Modern epidemiology. Boston: Little, Brown, 1986.

32 Lundberg M, Fredlund P, Hallqvist J, et al. A SAS program calculating three measures of interaction with confidence intervals. Epidemiology 1996;7;655-6.

33 Voss M, Floderus B. Sjukfrånvaron: trend och utsatta grupper. (Sickness absence: trend and exposed groups of employees.) In: Knave B, Floderus B, Grönkvist L, et al, eds Postmiliö 2000: arbetsliv $i$ utveckling Stockholm: National Institute for Working Life, 1993:18-40.

34 Vahtera J, Kivimäki M, Pentti J. Effect of organisational downsizing on health of employees. Lancet 1997;350:11248.

35 Hensing G, Alexanderson K, Allebeck P, et al. How to measure sickness absence? Literature review and suggestion of five basic measures. Scand F Soc Med 1998;26:13344.

36 National Board of Occupational Safety and Health and Statistics Sweden (SCB). Arbetsmiljön 1997. (The Working Environment 1997). Stockholm: Statistics Sweden, 1998.

37 Einarsen S, Skogstad A. Bullying at work: epidemilogical findings in public and private organizations. European fournal of Work and Organizational Psychology 1996;5:185-201.

\section{Rejected manuscripts}

Authors whose submitted articles are rejected will be advised of the decision and one copy of the article, together with any reviewer's comments, will be returned to them. The
Fournal will destroy remaining copies of the article but correspondence and reviewers' comments will be kept. 